\title{
Coasts, Marine Structures and Breakwaters 2009
}

Adapting to Change

\section{Keynote Presentations}

A series of keynote presentations will cover leading areas including:

- Progress towards realistic marine renewable energy extraction

- Understanding inherited infrastructure

- Debating the future of coastal management

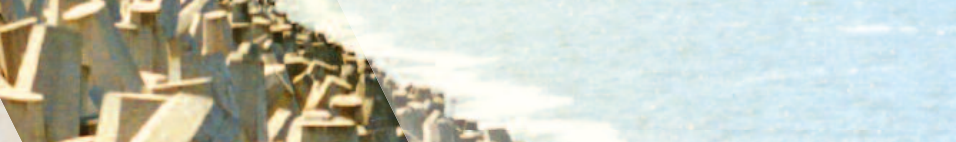

Institution of Civil Engineers
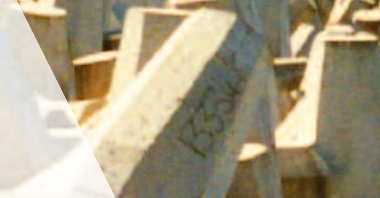


\section{CONFERENCE WELCOME}

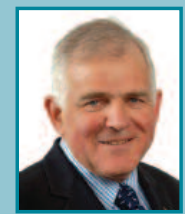

Jim Mather MSP

Minister for Enterprise, Energy and

Tourism, Scottish Government

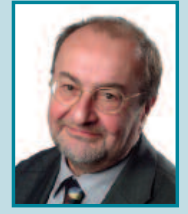

Prof Paul Jowitt

Senior Vice President and President

Elect, Institution of Civil Engineers

\section{OPENING PLENARY}

Progress towards a Viable UK Marine Renewable Energy

Prof lan Bryden, University of Edinburgh

Historical Experience of Vertical Breakwaters in the UK

Prof William Allsop, Technical Director of Maritime Structures, HR Wallingford and University of Southampton

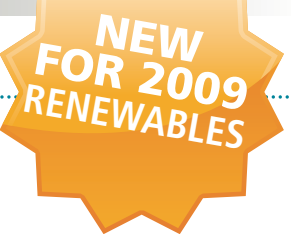

The Sea versus Wick Breakwater 1863-77: An Instructive Disaster

Prof Roland Paxton, Heriot-Watt University

Breakwater Development in Spain: The Last Ten Years

Ramón Gutiérrez-Serret, Director of the Maritime Experimental Laboratory, CEDEX, and Secretary General, IAHR

\section{LUNCH}

\section{STREAM A}

\section{SHORELINE MANAGEMENT}

Dee Estuary Evolution: An Expatiation

Dr Philip Barber, Senior Partner, Shoreline Management

Partnership

Global Warming Influences on Tidal Wetland in Japan

Dr Hajime Tanji, Laboratory of River and Coastal Engineering

The Water Framework Directive and the Management of Physical Habitats in Estuaries and Coasts

Dr Lucy Bolton, Technical Advisor, Hydromorphology, Environment Agency

Coastal Flooding in Scotland: Past, Present and Future Dr Tom Ball, Academic Research Fellow, University of Dundee

\section{STREAM B}

\section{RENEWABLES}

Developing Standards for the Marine Energy Industry John Griffiths, Technical Director, EMEC

The Development of Technology Evaluation Protocols for the Equitable Evaluation of Marine Renewable Energy Converters

Dr David Ingram, Reader, University of Edinburgh

Tidal Power from the Estuaries of Northwest England Terry Hedges, Senior Lecturer, University of Liverpool

Developing further Understanding of Site Selection fo Harvesting Tidal Current Energy: Sites Dominated by Tidal Streaming

Dr Scott Couch, Senior Research Fellow, University of Edinburgh

Composite Seawalls for Wave Energy Conversion Dr Gerald Müller, Senior Lecturer, University of Southampton

\section{STREAM C}

\section{HYDRODYNAMICS}

Modification of the Goda Formula to Evaluate the Movement of a Caisson Breakwater Protected by Failed Armour

Dr Miguel Esteban, Post-Doctoral Fellow, United Nations University Institute of Advance Studies

Dynamic Analysis of Fluid-elastic Solid Interaction Using the Moving Particle Semi-implicit Method Toshinori Ogasawara, Assistant Professor, Iwate University

Large Scale Simulations on Impulsive Wave Pressures by Using CADMAS-SURF/3D

Dr Taro Arikawa, Senior Researcher, Port and Airport Research Institute

Physical Modelling of Violent Flows and their Impact using a New Tsunami Generator

Tristan Lloyd, PhD Student, University College London

Resonant Fluid Motions in Joint Gap of Caisson-type Breakwater under Random Wave Attack

Dr Takehisa Saitoh, Associate Professor, Kanazawa University

\section{COASTAL DEFENCES}

Storm Damage and Rehabilitation of Coastal Structures on the East Coast of South Africa

David Phelp, Research Group Leader, CSIR

Damage from Waves, Surges and Overtopping at Vertical Seawalls

Dr Vanesa Magar, RCUK Academic Fellow, University of Plymouth

Optimization of a Step-berm Embankment

Dr Jeffrey Melby, Head, Coastal Structures Group, US Army

Engineer Research and Development Center

Engineering Site Selection Considerations for Reclamation Seawalls in the Hong Kong Special

Administrative Region

Alexander Mackay, Associate, Hyder Consulting

Flare-shaped Revetments: Installation Experience and Results on Sensitivity of Design to Climate Change

Prof Isao Irie, Kyusha University, and IDEA Consultants

\section{AFTERNOON COFFEE BREAK}

\section{RENEWABLES}

Competitive Concrete Gravity Base Foundations for Offshore Wind Farms

William Brook-Hart, Technical Director, Gifford

Ocean Brick System (OBS) as a Foundation Structure for Offshore Wind Turbine: An Experimental Study for Wave Loads and Stability

Andreas Kortenhaus, Senior Researcher, Technical University of Braunschweig

Landing Marine-derived Renewable Energy: Optimising

Routing of Electricity Cables in the Nearshore to

Offshore Environment

Dr Rosalind Turner, Coastal Scientist, Mott MacDonald

Construction Planning for the Greater Gabbard

Offshore Wind Farm

David Summers, Construction Manager, Fluor

Scour Around Gravity-based Wind Turbine Foundations:

Prototype Measurements

Annelies Bolle, Project Engineer, International Marine

and Dredging Consultants

\section{BREAKWATERS}

Single Layer Armour Systems: Toe, Crest and Roundhead Details

Phil Besley, Group Manager, HR Wallingford

On the Design of Quasi-static Berm Breakwaters Dr Otavio Sayao, Senior Engineer, Sandwell Engineering Development of an Icelandic-type Berm Breakwater for the Oakajee Port Project in Western Australia Sigurdur Sigurdarson, Senior Coastal and Harbour Engineer, Icelandic Maritime Administration

Design to Construct

Gerard Spaan, Senior Engineer, Van Oord Dredging and Marine Contractors

Offshore Breakwater Design Optimization for the Argentine Coastal Protection

Prof Rocío Fernández, National University of Cordoba 


\section{SHORELINE MANAGEMENT}

An Innovative Tool for Improving Stakeholder Engagement

Kevin Burgess, Executive Director, Maritime Business, Halcrow Group

Coastal Defences: Social Utility, Imagination and Justice Jonathan Simm, Technical Director, HR Wallingford

A Performance Based Assessment of Design Tools and Design Conditions for a Beach Management Scheme Prof Andrew Bradbury, Director, Channel Coastal Observatory

Energy and Carbon Costing of Breakwaters Dr Tom Bruce, Senior Lecturer, University of Edinburgh

\section{RENEWABLES}

Wave Induced Dynamic Pressures on a 150 kw Capacity OWC Prototype Wave Energy Caisson Prof Kannapiran Thiruvenkatasamy, Head, Department of Harbour Engineering and Offshore Technology, AMET University

Experience Gained from the Design and Construction of Oyster, a Nearshore Surging Wave Power Device Prof Trevor Whittaker, Queens' University Belfast

The Construction and Commissioning of the Mutriku Multiple Oscillating Water Column Breakwater Dr Tom Heath, Chief Technology Officer, Wavegen

Development of a Generic Caisson Design for an Oscillating Water Column Power Generator Steven Preen, Chief Engineer, Heavy Civil Structures, Halcrow Group

\section{BREAKWATERS}

Rehabilitation of Yzerfontein Breakwater by Dolos Armour Units

Masupha Letsie, Coastal Engineer, CSIR

Cost Effectiveness of the Renovation Scenarios of the IJmuiden Breakwaters

Hans Janssen, Senior Advisor, Hydraulic Engineering,

Rijkswaterstaat

Breakwater Construction at New Port in Punta

Langosteira, A Coruña, Spain: Execution Process and Technical Innovation

Enrique Maciñeira-Alonso, General Manager, Port Authority of $A$ Coruña

Final Rehabilitation of Sines West Breakwater: Physical and Numerical Modelling of Overtopping

Dr Maria Teresa Reis, Research Officer, National Civil Engineering Laboratory

Rehabilitation of the Old Cube Breakwater of Port of Poti, Georgia, with Xbloc ${ }^{\circledast}$ Armour Units

Pieter Bakker, Senior Coastal Engineer, Delta Marine Consultants

\section{SHORELINE MANAGEMENT}

Re-building East Anglia's Beaches

Steve Hayman, Coastal Advisor, Environment Agency

The Design and Performance of a Detached Breakwater and Beach Recharge in a Crenulate Bay:

A Case Study, Newbiggin-by-the-Sea, Northumberland lain Roberts, Associate Maritime Engineer, Atkins

Precautionary versus Reactionary Adaptation to Coasta Climate Change: Local Solutions to this Global Problem Mike Attwell, Regional Delivery Manager, Environment Agency

Coastal Monitoring and Analytical Work on the

'Dynamic' Anglian Coastline

Nigel Pask, Project Manager, Environment Agency

Coastal Defences and Biodiversity: The Influence of Material Choice and Small-scale Surface Texture on

Biological Outcomes

Martin Coombes, PhD Postgraduate, University of Exeter

\section{MORNING COFFEE BREAK}

\section{RENEWABLES}

Analysis of the Wave Energy Resource at the European Marine Energy Centre

Dr Matt Folley, Senior Research Fellow, Queen's University Belfast

Development of Wave Energy Breakwater at Siadar, Isle of Lewis

Christopher Patterson, Technical Director, Ports and Maritime Jacobs Engineering

Overtopping Performance of Sea Wave Slot Cone Generator Dr Jens Peter Kofoed, Associate Professor, Aalborg University

WaveRush: A New Concept for a Breakwater Wave Energy Converter

lain Roberts, Associate Maritime Engineer, Atkins

\section{BREAKWATERS}

An Overview of the Construction of the Core-locTM Armoured Breakwater at Newbiggin-by-the-Sea,

Northumberland Andrew Wareing, Engineer, Atkins

Innovative Technique for Single Layer Armour Unit Placement: An Example of Increased Production Efficiency whilst Improving Health and Safety Peter van Geldere, Senior Engineer, Van Oord Dredging and Marine Contractors

Armour Unit Placement and Positioning in 3D Real Time Alain Mouquet, Managing Director, MESURIS

Post-construction Monitoring of a Core-loc ${ }^{T M}$ Breakwater using Tripod-based LiDAR

Jessica Podoski, Coastal Engineer, US Army Corps of Engineers

Stochastic Risk-Based Life Cycle Simulation of Century Old Jetties at the Mouth of the Columbia River, USA Hans Moritz, Hydraulic and Ocean Engineer, US Army Corps of Engineers

\section{LUNCH}

\section{COASTAL DEFENCES}

Saltcoats Flood Prevention Scheme: Analysis, Design and Construction

Dr Elizabeth Johnson, Engineer, Royal Haskoning

The Construction of Weston-super-Mare Sea Defences and Seafront Enhancements

Christopher Hill, Project Manager, Birse Coastal

Rehabilitation of the Revetment along Galle Marine Drive Tharanga Pemasiri, Engineering Manager, Lanka Hydraulic Institute

Sustainable Coastal Defences for Felixstowe Andrew Rouse, Project Manager, Environment Agency

Applying the Artificial Submerged Reefs Techniques to Reduce the Flooding Problems along the Alexandria Coastline

Dr Akram Soliman, Associate Professor, Arab Academy for Science and Technology and Maritime Transport

\section{COASTAL RESPONSES TO STRUCTURES}

Simulation of Long-term Beach Changes within a Flood Defence Scheme

Prof Dominic Reeve, University of Plymouth

Towards Design Guidance for Nearshore Detached Breakwaters on Macro-tidal Coast

Hakeem Johnson, Associate Director, Halcrow Group

Beach Nourishment Modelling: Impact of Coastal Structures Dr Shunqi Pan, Reader in Coastal Engineering, University of Plymouth

Morphological Change of Nourished Beach Fronted by Nearshore Structures

Amy Taylor, PhD Student, University of Aberdeen

Numerical Modelling Morphodynamics of Offshore

Breakwaters Using an Improved Q3D Model

Dr Ming Li، Lecturer, University of Liverpool

\section{BREAKWATERS}

Extending the Life of Brighton Marina Breakwaters from 30 to 130 Years

Jonathan Orrell, Managing Director, Hemsley Orrell Partnership

Installation of Caisson Breakwater at Costa Azul,

Mexico

Martin Young, Deputy Chief Resident Engineer, Scott Wilson

Foundations to Precast Marine Structures

Martin Hawkswood, Director, Proserve

Restoration of St Catherine's Breakwater Roundhead, Jersey, Channel Islands

Steve Hold, Associate, Arup

The Influence of the Crown Wall on the Design of a

High Crested Composite Breakwater

Neil Bevan, Project Manager, Mouche

\section{COASTAL DEFENCES}

Polyurethane Bonded Aggregate (PBA) Revetments in Coastal Engineering

Egon Bijlsma, Junior Specialist, Flood Defences, ARCADIS

The Study and Development of a New Structure for Coastal Protection

Matteo Zanella, Technical Manager, Coastal Protection System

\section{AFTERNOON COFFEE BREAK}

\section{METOCEAN}

Evaluating Potential Implications of Cumulative Storm Power on Coastal Infrastructure Damage and Shoreline Erosion Heidi Moritz, Coastal Engineer, US Army Corps of Engineers

Tropical Cyclone Gonu: Post Event Wave Modelling Nicholas Elderfield, Coastal Engineer, Atkins

Marine Forecasts for the Safe Construction and

Maintenance of Coastal Structures

Nigel Tozer, Principal Scientist, HR Wallingford

Tsunami Inundation Modelling and Risk Assessment:

City of Galle, Sri Lanka

Prof Sam Hettiarachchi, University of Moratuwa

\section{DESIGN GUIDANCE}

HYDRALAB III: Guidelines for Physical Model Testing of Rubble Mound Breakwaters

Dr Guido Wolters, Advisor and Researcher, Deltares-Delft Hydraulics

Introducing the New Ciria Manual on the Use of

Concrete in the Maritime Environment

Dr Sébastien Dupray, Coordinator of Methods and Research for Structures, CETMEF 


\section{Friday 18 September 2009}

\section{STREAM A}

EROSION RISK

From Failure to Success: Update on the Vero Beach P. E. P. Reef ${ }^{\top M}$, Indian River County, Florida Adam Priest, Maxwell Marine Consulting Engineers

Coastal Erosion in Uruguay

Guillermo López-Méndez, Assistant Professor and Researcher,

University of the Republic

A Rock and a Hard Place: Managing Coastal Erosion

Risk at Trow Quarry, South Shields

Dr Nick Cooper, Technical Director, Royal Haskoning

Vulnerability to Climatic Changes with a 2DH Modelling

on Four French Beaches

Philippe Larroudé, Assistant Professor, Joseph Fourier University

Beyond Sustainability

Vicki Kelly, Director, Koru Coaching UK

\section{STREAM B}

\section{OVERTOPPING}

A Comparison of Field Measurements, Laboratory Measurements and Probabilistic and Empirical Wave Overtopping Predictions

Tim Pullen, Senior Engineer, HR Wallingford

Overtopping and Scour at Vertical Seawalls Dr Jonathan Pearson, Assistant Professor, University of Warwick

Towards a Unified Approach for Design of Overtopped Coastal Structures

John Headland, Senior Vice President, Moffatt \& Nichol

Riprap Stability for Deep Water, Shallow Water and Steep Foreshores

Marcel Mertens, Structural Engineer, BAM Infraconsult

\section{STREAM C}

\section{PORTS}

Expansion of Jebel Ali Port

Dennis Padron, Executive Vice President, Halcrow Group

Expansion Works to the Port of Salalah, Oman Cleanthis Lambrou, Project Manager, Archirodon Construction Innovation in the Extension to the Port of Gijón José Luis Díaz-Rato, General Manager, Gijón Port Authority Isles of Scilly Link Harbour Improvements: Social and Environmental Issues in a Unique Island Location Gareth Robertshaw, Senior Engineer, Halcrow Group

Dredging Innovations for Dames Point Container Terminal, Jacksonville

Dr Paul Starr, Regional Manager, Jacksonville, Halcrow Group

\section{MORNING COFFEE BREAK}

\section{EROSION RISK}

\section{OVERTOPPING}

Guidance on Erosion Resistance of Inner Slopes of Dikes from Three Years of Testing with the Wave Overtopping Simulator

Dr Jentsje van der Meer, Principal, Van der Meer Consulting BV Flow Parameters of Combined Wave Overtopping and Storm Surge Overflow of a Trapezoidal Levee Dr Steven Hughes, Senior Research Hydraulic Engineer, US Army Engineer Research and Development Center

Modelling of Sohar Intake Breakwater Dr Ali Riza Günbak, Partner, ARG Coastal Engineering Company

Effect of Protruding Roughness Elements on Wave Overtopping

Dr Alison Hunt-Raby, Lecturer, University of Plymouth

\section{MARINAS}

The New Marina of Rodi Garganico: Design, Construction and Monitoring Prof Leopoldo Franco, University of Roma 3, and consultant. MODIMAR

Physical Modelling of the Mechanical and Hydrodynamic Behaviour of Reinforced Concrete Floating Breakwaters: Application in Baiona (Galicia, Spain)

Dr Enrique Peña-González, Associate Professor, University of $A$ Coruña

Preliminary Design Studies for a Multifunctiona Artificial Surf Reef on the Carrara Coast, Italy Damiamo Scarcella, PhD Student, University of Rome 3

\section{LUNCH}

\section{FRINGE}

In addition to the formal papers a number of short technical notes, announcements and position papers will be presented.

\section{FRINGE}

In addition to the formal papers a number of short technical notes, announcements and position papers will be presented.

\section{ARMOURING}

Cube and Cubipod Armour Unit Drop Tests and Cost Analysis Prof Josep Medina, Technical University of Valencia Evolution of Damage on Roundheads Protected with Cubes and Cubipod Armour Units Dr Pedro Lomónaco, Senior Research Officer, University of Cantabria

Reliability Analysis of Breakwater Armour Blocks of Harbours in Korea Seung-Woo Kim, PhD Student, Seoul National University Risk Awareness: Key to a Sustainable Design Approach for Breakwater Armouring Bas Reedijk, Head of the Coastal Department. Delta Marine Consultants

Review of the Use of Concrete in the Manufacture of Concrete Armour Units

Dr Sébastien Dupray, Coordinator of Methods and Research for Structures, CETMEF

\section{AFTERNOON COFFEE BREAK}

\section{CLOSING PLENARY}

Managing our Coast: A Strategic View Alison Baptiste, Area Coastal Manager, Environment Agency

One Hundred and Beyond: Using Shoreline Management Plans

Gregor Guthrie, Principle Coastal Engineer, Royal Haskoning

UK Shoreline Management Planning: Enlightened or Occult

Dr Philip Barber, Senior Partner, Shoreline Management Partnership

Louisiana's Comprehensive Master Plan for a Sustainable Coast: A Response to Hurricanes Katrina and Rita in 2005

Ben Hamer, Director, Maritime, UK, Europe and Central Asia, Halcrow Group 


\section{Extra Activities}

\section{Social Programme}

\section{Explore Edinburgh}

Three different activities are offered to conference delegates and their guests on the evening of Thursday 17 September. All choices are centred on the upper part of the Royal Mile, in Edinburgh's historic Old Town, part of the UNESCO World Heritage area.

Old Town Walking Tour - the ideal introduction to the splendid Old Town of Edinburgh.

Camera Obscura Reception - enjoy fantastic views of Edinburgh and three galleries packed full of optical experiences.

Whisky Tasting - be introduced to the world of Scotch whisky in this relaxed experience.

\section{Conference dinner}

The conference will conclude with a dinner offered to all delegates on Friday 18 September at Our Dynamic Earth, a unique venue featuring stunning views of the Salisbury Crags, the Palace of Holyroodhouse and the Scottish Parliament. The conference dinner is included in the conference fee and must be booked in advance. Guests are welcome to join this special occasion.

\section{Technical visit}

A full day technical visit will take place on Saturday 19 September It will feature visits to St Andrews and the harbours of Buckhaven and East Wemyss, concluding with a boat trip which will allow you to enjoy the spectacular views of the Forth Bridge. This impressive tour is recommended for both delegates and their guests.

\section{Additional sessions}

\section{Pre-conference short course}

On Tuesday 15 September the University of Edinburgh will host a one-day short course on the Design of Coastal Structures, presenting a focussed summary of key recent developments in this field. Attendees will be introduced to new manuals and guidance, receive technical updates covering specific areas which have seen rapid research advances in recent years and have the opportunity to engage with an international panel of experts.

\section{Conference fringe}

In addition to $\mathbf{1 1 0}$ formal papers, the conference organisers will also accept a number of short technical notes, announcements and position papers for less formal presentation. Registered attendees interested in taking part in the conference fringe must submit an abstract by Tuesday 30 June.

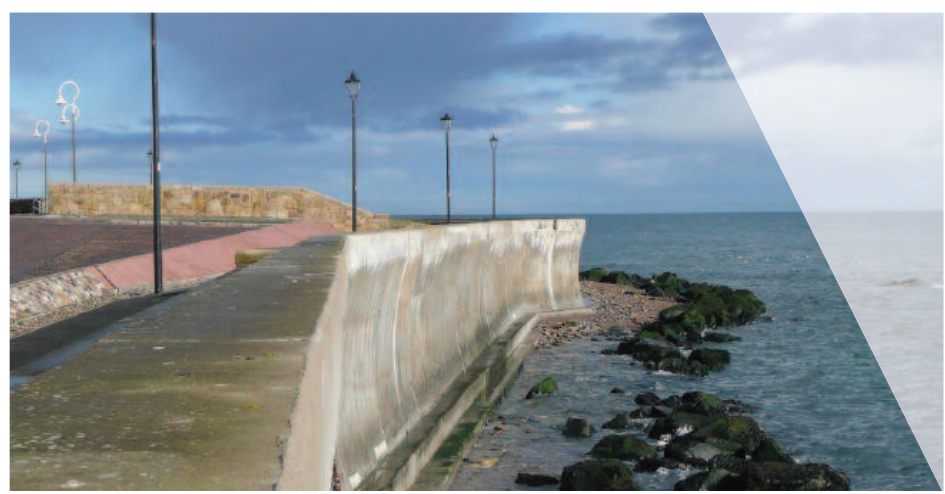

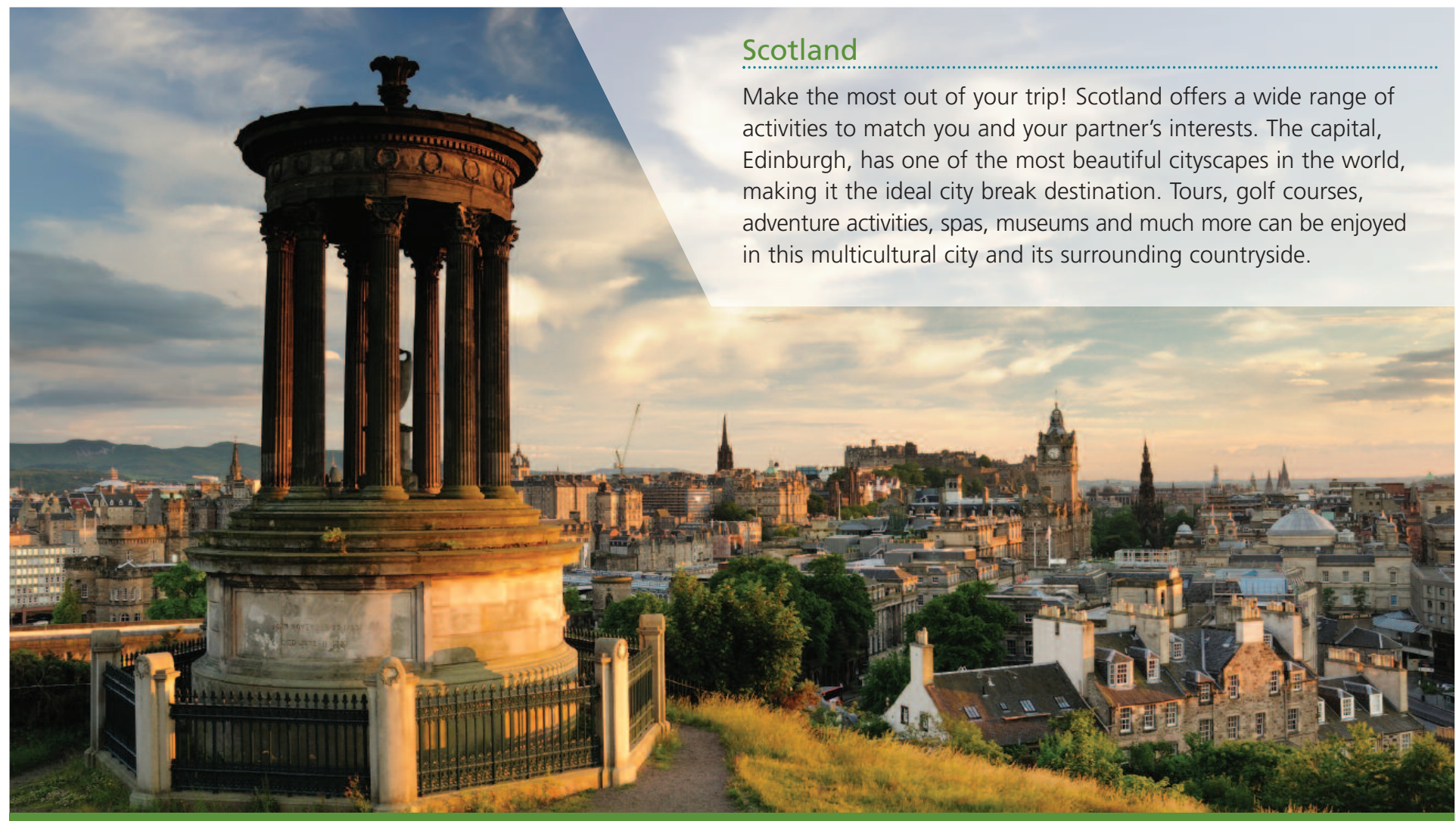




\section{Fees and discounts}

$$
\text { Package }^{1}
$$

ICE/Supporting Non member organisation member

Conference $^{2}$

£595

f695

Conference $^{2}+$ Short course $^{3}$

Conference $^{2}+$ Technical visit ${ }^{4}$

$\mathrm{f} 694$

£794

Conference $^{2}+$ Short course $^{3}+$ Technical visit $^{4}$

f645

f745

$\mathrm{f744}$

£844

\section{Short course only ${ }^{3}$}

f99

f99

Conference dinner ${ }^{5}$ (guest)

$\mathrm{f} 70$

Technical visit ${ }^{4}$ (guest)

f50
f70

\section{All prices are excluding 15\% VAT.}

2 Includes access to all conference sessions and the exhibition area, refreshment breaks and lunches, the drinks receptions on Wednesday 16 and Thursday 17 September, the conference dinner on Friday 18 September and a printed copy of the full conference proceedings to be produced after the event. Conference proceedings will be mailed to attendees. Postage and packaging costs are not included in the conference fee.

3 Will take place on Tuesday 15 September. It includes refreshment breaks and lunch.

4 Will take place on Saturday 19 September. Lunch is not included. Guests are encouraged to participate.

5 Will be held on Friday 18 September at Our Dynamic Earth. Guests must book in advance.

6 Conference proceedings will be mailed after the event. Postage and packaging costs are not included in the conference fee.

Terms and conditions apply and can be found on the conference website.

\section{Sponsorship and exhibition opportunities}

A limited number of sponsorship and exhibition packages are still available. Sponsoring or exhibiting at this event will allow your organisation to generate new leads, position your brand as a key player in the coastal engineering industry and associate your business with the professionalism and excellence the Institution of Civil Engineers stands for.

For more information and a personalised sponsorship proposal please contact Norman Anand, Sponsorship and Exhibition Manager, at norman.anand@ice.org.uk or +44 (0)20 76652215 or +44(0)7984606668.

\section{Contact us}

For any programme related queries please contact David Rodriguez-Vega, Conference Producer david.rodriguez-vega@ice.org.uk +44 (0)207665 2310

For any media partnership opportunities please contact Javi Rua, Senior Marketing Executive

javi.rua@ice.org.uk +44 (0)20 76652298

For any registration and venue related queries please contact Hayley Clarke, Events Operations Executive hayley.clarke@ice.org.uk +44(0)207665 2151

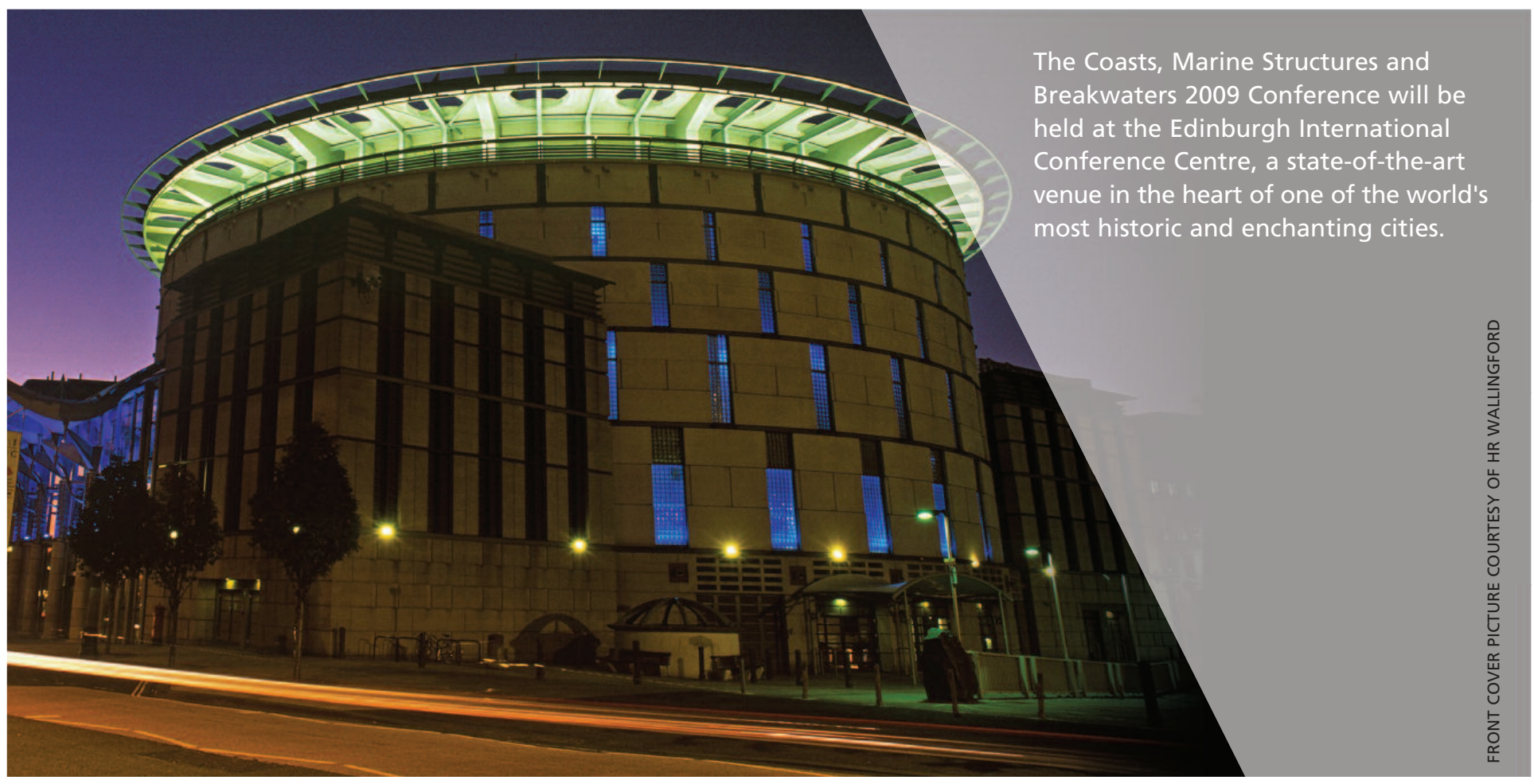

